\title{
SEASONAL FOOD AND PREY RELATIONSHIPS OF BADGERS IN EAST-CENTRAL ALBERTA
}

JIM R. SALT, 8731 - 117 St., Edmonton, Alta. T6G 1R6

A general mammal inventory and preliminary studies was undertaken 45 $\mathrm{km}$ (28 mi.) SE of Wainwright by the author in the summer of 1975 for the Provincial Parks Planning and Design Branch. This project was part of an ecological assessment of a relatively undisturbed region $\left(110^{\circ} 45^{\prime}\right.$ and $110^{\circ}$ $35^{\prime}, 52^{\circ} 37^{\prime}$ and $\left.52^{\circ} 33^{\prime}\right)$. The major topographic features are the Ribstone Creek and marsh system, flowing along the west side of the area, then east and northward again through the southeast sector: an extensive tract of sandridges, elevated as much as $150 \mathrm{~m} \mathrm{(490}$ ft. north boundary) above the Ribstone system; three major lakes, Wallaby and Border in the northwest and David Lake in the southeast; and a considerable mixture of sand-ridge/marsh where the two ecosystems meet one another in the south-central area.

A complete mammal and bird checklist of this unique area is currently in preparation. The present note relates to the badger (Taxidea taxus) and related species, with particular reference to seasonal changes in food-supplies and feeding habits. The population of badger in the study-area was widespread, and signs of activity as well as the animals themselves, were encountered in all the sand-ridge systems, pastures and isolated extensions into the marshes and willow (Salix) bogs. Movement of the species across the Ribstone Creek system was facilitated by several weirs for flood control. Feces, tracks and the badgers were seen on the dykes leading to these weirs. But access to the insular sandridges in the marshes and bogs (west of David Lake, etc.) required that the animals traverse both extensive $(0.5$ to $1.5 \mathrm{~km}, 0.3-0.9 \mathrm{mi}$.) poplar tracts and wet bog-marsh habitat for total distances of from 1 to $2.5 \mathrm{~km}$ (0.6-1.6 mi.). In spite of this, all evidence suggested that the species had traversed this terrain at least twice in the springsummer and early autumn of 1975 . The first visit to the region, June 19, revealed a small degree of very recent badger activity in the isolated sandridge systems. The age of these feeding-dens was estimated at not more than 2 weeks, from condition of soil-mounds, the number of feces found in them (usually buried), and their small numbers ( 1 or 2 dens average at each feeding site). All older badger digs at these sites were clearly of at least 10-12 months' old. On the main sand-ridge system north and east of Ribstone Creek, badger feeding dens were noted dating almost continuously from early spring (April?) to recent. The inference was that the animals on the insular sand intrusions among the marshes had only very recently occupied these territories.

Investigations in June, including analysis of the stomach-contents of 2 badgers killed by automobiles and of ca. 40 feces groups, proved that the major food at time of the visit was pocket gopher (Thomomys talpoides). These were easily identifiable in the field by the presence of largely undigested forefeet of the animals, of which at least one, and usually 2 individuals were found in each fecal group (i.e., 2 in each stomach). The June investigation showed that Richardson's ground squirrel (Spermophilus richardsoni) formed a minor part (10 to $40 \%$ by number) of the badgers' diet.

During the June and subsequent studies, populations of pocket gopher, 


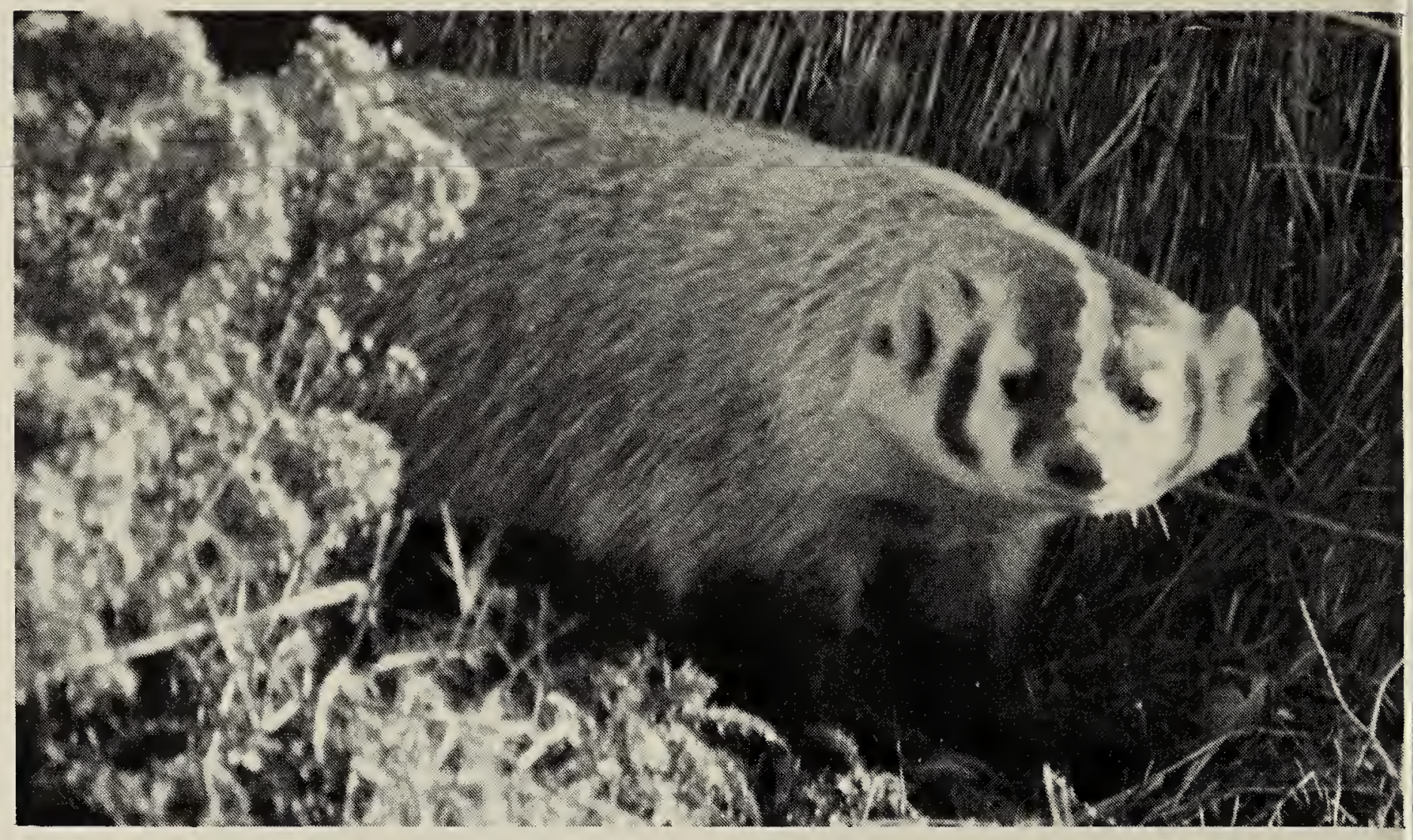

Badger.

L. A. Morgotch

Richardson's ground squirrel and the voles and mice (Microtus, Peromyscus and Clethrionomys) were surveyed by live and snap-trap methods, as well as by fecal and pellet analyses, nest counts, etc. Of these species, only Microtus was noted in the diet of the badgers. Some brief comments on the primary food-items of the badgers are presented below to the subject-species.

Richardson ground squirrel: A number of small colonies, some among the roots of willow clumps with Saskatoon berry (Amelanchier alnifolia) and some in extensive tracts of buckbrush (Symphoricarpos (pauciflorus Robbins?)), were noted on sand-ridges and insular ridge-systems. All colonies of 20 or more adults, however, were in pastures or grazed meadows. No young were in evidence June 19, but one family of 5 very small young appeared briefly June 20 in a pasture near David Lake. From July $21-31,20 \%$ or fewer of the ground squirrels examined were adult, and of these, from $4 \%$ to $6 \%$ were males. By October 3 , possibly due in part to some inclement weather, only 5 ground squirrels of this species were observed.

Thirteen-lined ground squirrel (Spermophilus tridecemlineatus): Found in casual association with the badger, but there was no evidence that badgers used them for food.

Pocket gopher: More numerous and more generally distributed than Richardson's ground squirrel. It was found on all insular ridge-systems and uplands in the marsh-bog matrix, as well as on the sand-ridges and in damp meadows and pastures near the lakes. Series of mounds extending from the upper ridges down into recently dried marsh and pond-edges were fresh in mid-June, suggesting that the animals had recently moved downward with the retreating water table. Great activity was recorded for the species in June, when specimens and livetrapped individuals were $80 \%$ immatures (June 19-21). At this time, new mounds were noted at the rate of 2 to 3 per individual per 24 -hour period in all colonies studied. By opening the most recent mounds and leaving them exposed, I was able to obtain an estimate of reaction-time, the time elapsed before the opened den was plugged by the inhabitant. In mid-June average reaction time was 40 minutes, the longest being 70 minutes. Similar experiments and mound counts in late July indicated a great reduction in ac- 


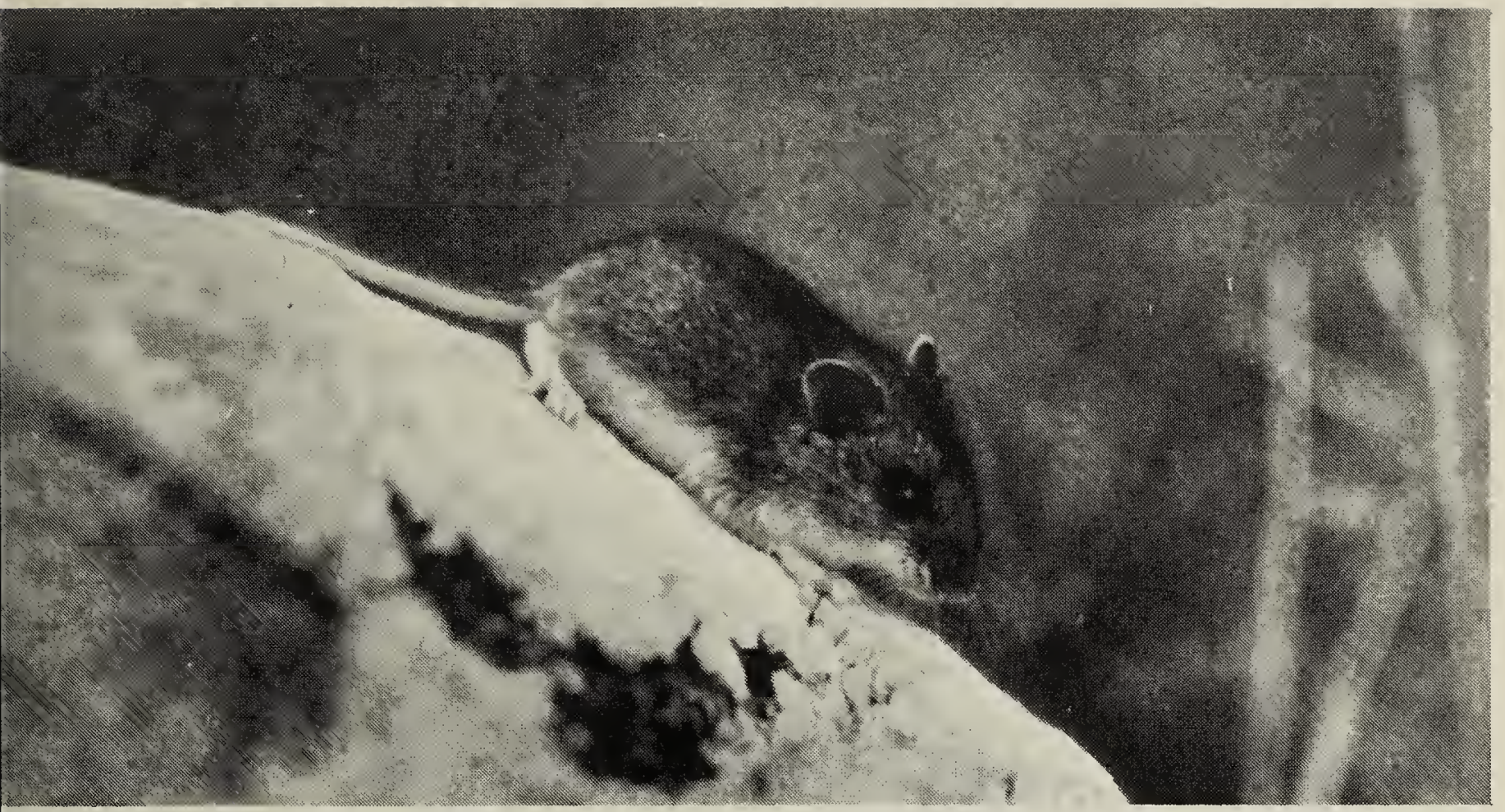

White-footed Mouse (Peromyscus).

ivity: new mounds were produced at a ate of less than 1 per 72 hours per inimal, and reaction time in plugging he opened dens often exceeded 4 hours. Investigations in early October howed that there had been coniderable activity, probably in late August and September, but by October 3 to 5 , new mounds were noted at a ate of less than one per 72 hours, and n many communities no new digging vas seen. The reaction time was as nuch as 20 hours at opened dens.

The June acitivity corresponds to he breeding of the species, the young f which begin feeding and digging in he last half of June. The only sightecords of pocket gopher were from his period, when young animals were ittle more than half grown and prowsed on grasses and forbs.

Analysis of badger feces and the tomach contents indicated that he species depended heavily upon pocket gophers in the period from late March or early April to early July. By ate July, however, the fecal analyses of recent samples showed a coniderable increase in use of Richardon's ground squirrels. The location of resh feeding dens - most of which vere old dens revisited and renovated - for the period July 18 to 29, favored he colonies of Richardson's ground squirrel: only $25 \%$ to $30 \%$ of active feeding dens at this time were associated with pocket gopher communities. Fecal analyses showed that badgers, from about mid-July, had resorted to Richardson's ground squirrel for about $66 \%$ of their food. with 5 to $10 \%$ plant material included in the diet.

In early October, the number of feeding dens of the badgers had decreased significantly at all sites; the number of active dens recorded was at most $25 \%$ that of the July count. About $3 / 4$ of these were in association with pocket gopher communities. Fecal analysis showed that in recent feces, pocket gopher accounted for 10 to $30 \%$ of food by weight: Richardson's ground squirrel was only $5-10 \%$. and the meadow vole (Microtus pennsylvanicus) was found in $68 \%$ of fecal groups. The vole represented a small proportion by weight, however, for no more than 2 individuals were found in any fecal group. The bulk (by quantity and by weight) of foods in the early October survey was insects, principally unidentified grasshopper and beetles. The latter accounted for 50 to $90 \%$ of the food in fecal groups from the sandridge system. The proportion was somewhat lower for insular areas of the marsh matrix. But most badger ac- 


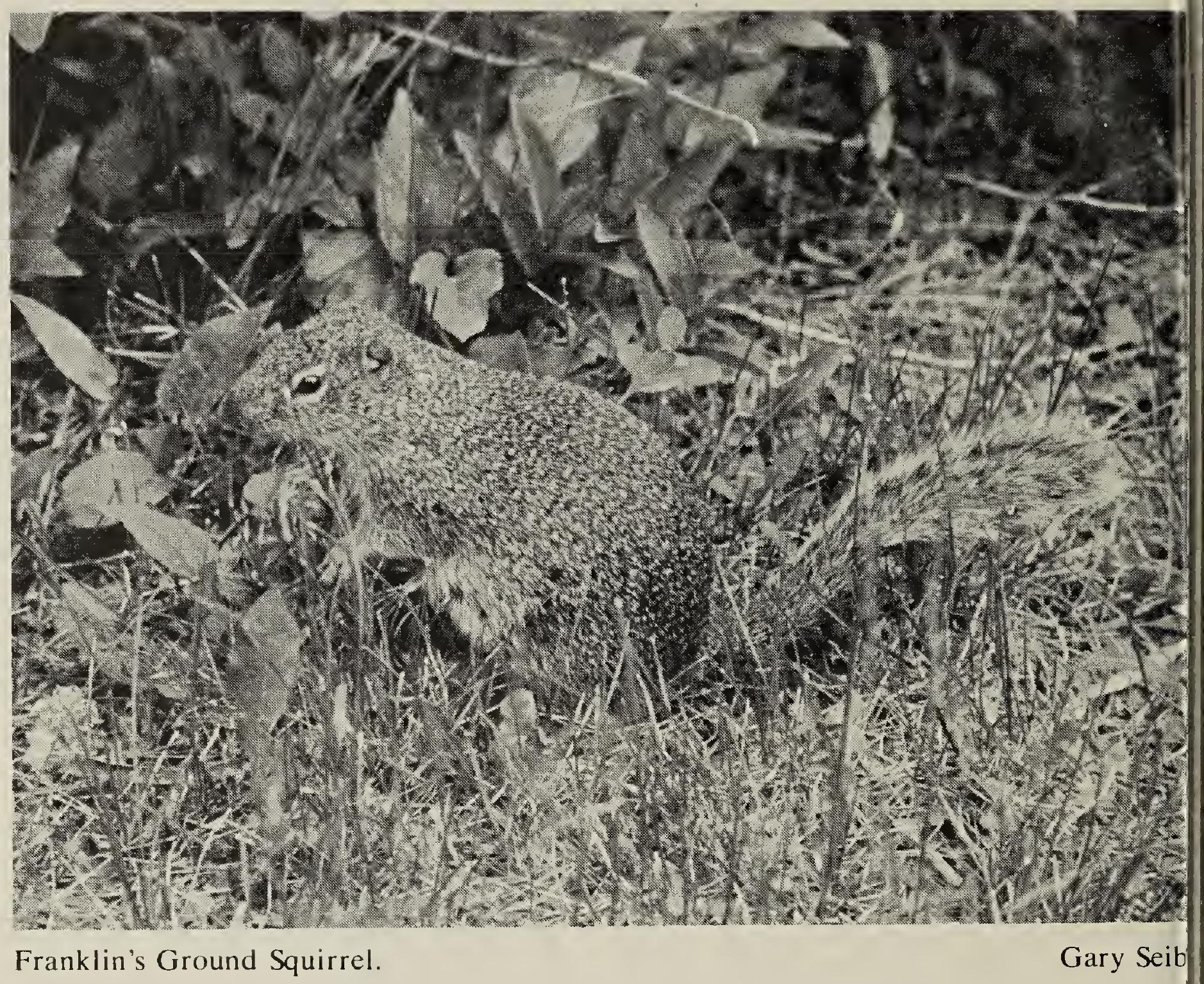

tivity recorded in early October was of a type unfamiliar to me, characterised by a profusion of small, shallow semicircular gouges, resembling the hoof-prints of cattle, and measuring 5 to $8 \mathrm{~cm}(2-3$ in.) in diameter and 3 to 7 cm (1-3 in.) deep. I examined dozens of such sites, at which the number of individual "digs" varied from 6 to 40 or 50. Feces of badger were almost always found at these sites, and the animals' tracks were often clear in the freshly-exposed sand. The feces here were not buried, as was usually the case at feeding dens. During the June reconnaissance, these peculiar marks had been noted on only one occasion. It is clear that these were sites at which badgers dug for beetles and other insects beneath the sparse grass and lichen.

After analysis of fecal and other data, if was found that feces from September-October collected at higher elevations (sand-ridge system) con-

tained a very high proportion of insect in particular, beetle remains, while those from low elevations in and beside the marsh matrix contained about $30 \%$ pocket gopher, $30 \%$ microtine, and $40 \%$ insect foods Three major beetles were: a june beetle (Phyllophaga anxia), the gold scarat (Cotalpa lanigera) and, less frequently a darkling beetle (Embaphior (muricatum?)). As aspen longhorr beetle (Saperda calcerata) was found ir one fecal group from the marsh-edge.

All evidence suggests that the badgers of this region, in order tc compensate for considerable fluc tuations in preferred food sources alter both feeding habits and feeding localities. The centres of feeding-site: are in many cases relocated, appar. ently twice annually, to distances of as much as $4 \mathrm{~km}$. 
